\title{
C-peptide is a bioactive peptide
}

\author{
J. Wahren • K. Ekberg • H. Jörnvall
}

Received: 8 June 2006 / Accepted: 24 October 2006 / Published online: 18 January 2007

(C) Springer-Verlag 2007

Keywords Endothelial nitric oxide synthase . Glomerular filtration rate $\cdot$ G-protein · Insulin disaggregation $\cdot$ Membrane binding $\cdot$ Microalbuminuria . $\mathrm{Na}^{+} / \mathrm{K}^{+}$-ATPase $\cdot$ Nerve conduction velocity $\cdot$ Red blood cell deformability

$\begin{array}{ll}\text { Abbreviations } \\ \text { BB/Wor } & \text { BioBreeding/Worcester } \\ \text { eNOS } & \text { endothelial nitric oxide synthase } \\ \text { ICAM-1 } & \text { intracellular adhesion molecule 1 } \\ \text { MAPK } & \text { mitogen-activated protein kinase } \\ \text { NCV } & \text { nerve conduction velocity }\end{array}$

During the past decade, reports from several laboratories have focused on the physiological effects of C-peptide. Experimental data and clinical studies suggest that that C-peptide is a biologically active peptide. Clinical studies show that C-peptide administration in type 1 diabetes patients, who lack the peptide, results in amelioration of diabetes-induced renal and nerve dysfunction. Molecular studies demonstrate binding to cell membranes, activation of intracellular signalling pathways, and specific end effects of importance for vascular endothelial function. These findings have prompted the hypothesis that C-peptide deficiency in

J. Wahren $(\bowtie) \cdot$ K. Ekberg

Department of Molecular Medicine and Surgery,

Karolinska Hospital,

17176 Stockholm, Sweden

e-mail: john.wahren@ki.se

H. Jörnvall

Department of Medical Biochemistry and Biophysics,

Karolinska Institute,

Stockholm, Sweden type 1 diabetes may contribute to the development of microvascular complications, and that $\mathrm{C}$-peptide replacement, together with regular insulin therapy, may be beneficial in the treatment or prevention of these complications. In the present article we argue the case in favour of C-peptide as a biologically active peptide based on in vivo data and in vitro findings, as summarised in Table 1.

Soon after the discovery of insulin biosynthesis in 1967, and the identification of C-peptide and its role in promoting the correct folding of proinsulin, researchers began to investigate whether C-peptide had any insulin-like effects. However, none were found, and interest in the peptide focused instead on its use as a marker of endogenous insulin secretion. Interest in a physiological role for C-peptide persisted, and received support from the clinical observation that patients with type 1 diabetes, who continue to maintain a small endogenous beta cell activity, are less prone to develop longterm complications and have fewer episodes of hypoglycaemia than those who become totally C-peptide deficient $[1,2]$. It was also noted that islet or pancreas transplantation in type 1 patients, with restoration of both insulin and C-peptide secretion, often results in amelioration of the functional and structural abnormalities that accompany diabetic neuropathy and nephropathy $[3,4]$. These considerations gave rise to a series of studies involving the administration of a replacement dose of C-peptide to type 1 diabetes patients.

\section{Beneficial effects on renal function and structure in type 1 diabetes}

Clinical studies Glomerular hyperfiltration, a risk factor for the development of nephropathy, is an early abnormality in type 1 diabetes that is not corrected by insulin therapy. This 
Table 1 Summary of clinical, in vivo animal and in vitro cellular effects of C-peptide

\begin{tabular}{|c|c|}
\hline Effect & Reference \\
\hline \multicolumn{2}{|l|}{ In vivo effects } \\
\hline \multicolumn{2}{|l|}{ Renal } \\
\hline Functional reserve $\uparrow$ & [7] \\
\hline Glomerular hyperfiltration $\downarrow$ & {$[5,7]$} \\
\hline Urinary albumin excretion $\downarrow$ & {$[6]$} \\
\hline Structural abnormalities $\downarrow$ & {$[8]$} \\
\hline \multicolumn{2}{|l|}{ Nerve } \\
\hline Conduction velocity $\uparrow$ & {$[9,10,12,13,37]$} \\
\hline Vibration perception $\uparrow$ & {$[10]$} \\
\hline Blood flow $\uparrow$ & {$[13,20]$} \\
\hline $\mathrm{Na}^{+} / \mathrm{K}^{+}$-ATPase activity $\uparrow$ & {$[12,37]$} \\
\hline Hyperalgesia $\downarrow$ & {$[14]$} \\
\hline Structural abnormalities $\downarrow$ & {$[12,15]$} \\
\hline \multicolumn{2}{|l|}{ Circulation } \\
\hline Muscle blood flow $\uparrow$ & {$[16]$} \\
\hline Skin blood flow $\uparrow$ & {$[19]$} \\
\hline $\begin{array}{l}\text { Myocardial blood flow and } \\
\text { contraction rate } \uparrow\end{array}$ & {$[17,18]$} \\
\hline Myocardial ejection fraction $\uparrow$ & {$[17,18]$} \\
\hline QT interval $\downarrow$ & \\
\hline \multicolumn{2}{|l|}{ In vitro effects } \\
\hline \multicolumn{2}{|l|}{ Membrane interaction } \\
\hline Specific binding in nanomolar range & {$[22,23]$} \\
\hline \multicolumn{2}{|l|}{ Intracellular signalling } \\
\hline G-protein involvement & {$[25-29]$} \\
\hline Intracellular $\mathrm{Ca}^{2+} \uparrow$ & {$[27,30]$} \\
\hline PKC, MAPK and PI-3K $\gamma \uparrow$ & {$[26,28,31]$} \\
\hline NFkB, PPAR $\gamma$, Bcl2, c-Fos, ZEB $\uparrow$ & {$[29,36,46]$} \\
\hline \multicolumn{2}{|l|}{ End effects } \\
\hline eNOS activity and protein levels $\uparrow$ & {$[30,33,34]$} \\
\hline $\begin{array}{l}\mathrm{Na}^{+} / \mathrm{K}^{+} \text {-ATPase activity } \\
\quad \text { and protein levels } \uparrow\end{array}$ & {$[25,31,36]$} \\
\hline Cell growth $\uparrow$ & {$[40]$} \\
\hline Apoptosis $\downarrow$ & {$[29,40]$} \\
\hline Insulinomimetic effects & {$[32]$} \\
\hline Anti-thrombotic effects & {$[21]$} \\
\hline \multicolumn{2}{|l|}{ Other } \\
\hline Disaggregation of insulin hexamers & {$[41]$} \\
\hline
\end{tabular}

$P I-3 K \gamma$, phosphatidylinositol 3-kinase $\gamma ; P K C$, protein kinase $\mathrm{C} ; Z E B$, zinc finger homeodomain enhancer-binding protein

prompted studies of the effects of C-peptide on kidney function. Short-term C-peptide infusion in young patients without signs of manifest nephropathy was shown to decrease GFR and to modestly increase renal plasma flow [5]. Subsequently, it was established that both GFR and urinary albumin excretion were diminished following C-peptide replacement therapy for 3 months in patients with early stage nephropathy. Specifically, in a doubleblind, placebo-controlled, crossover study in patients with no other medication except insulin, there was a $40 \%$ reduction in albumin excretion during 3 months of C-peptide replacement [6]. The results were seen as a direct effect of C-peptide, since both systemic blood pressure and glycaemic control were similar during the C-peptide and placebo treatment periods.

Animal studies C-peptide administration in streptozotocininduced diabetic rats for periods of up to 4 weeks resulted in a concentration-dependent correction of glomerular hyperfiltration, augmented renal functional reserve and diminished or abolished urinary albumin excretion $[7,8]$. The specificity of the C-peptide effect was verified in control studies involving infusion of scrambled C-peptide - a peptide with the same residues but in random order-that showed no effect. Microscopic examination of the kidneys showed glomerular hypertrophy in the diabetic animals and a substantial reduction of the glomerular expansion after C-peptide replacement. Further examination of the glomeruli revealed that it was primarily the hypertrophy of the mesangial matrix that was inhibited by C-peptide [8]. The results thus support the notion that $\mathrm{C}$-peptide administration exerts beneficial renal effects in type 1 diabetes.

C-peptide in replacement doses reduces glomerular hyperfiltration, diminishes urinary albumin excretion and retards or reverses renal structural abnormalities in type 1 diabetes.

\section{Amelioration of nerve dysfunction and structural abnormalities}

Clinical studies The effects of C-peptide on nerve dysfunction in type 1 diabetes were evaluated in a double-blind, placebo-controlled, 3-month study, including 46 patients with relatively short diabetes duration (10 years) and reduced sensory and motor nerve conduction velocity (NCV) but no overt signs of neuropathy [9]. Sensory (sural) NCV increased progressively in the group that received C-peptide treatment; the increase after 3 months was $2.7 \mathrm{~m} / \mathrm{s}$, corresponding to $80 \%$ correction of the initial NCV deficit. Vibration perception thresholds decreased during treatment, consistent with improved sural nerve function. These observations have been extended in a subsequent double-blind, placebo-controlled, clinical trial involving 161 type 1 patients with manifest diabetic peripheral neuropathy [10]. Sensory NCV improved in the $\mathrm{C}$-peptide treated patients, and the number of positive responders was greater among the patients receiving $\mathrm{C}$-peptide than those given placebo $(p<0.03)$. The improvement compared with placebo was most marked $(1 \mathrm{~m} / \mathrm{s})$ in the least severely diseased half of the patients $(p<0.02)$, emphasising the benefit of early intervention. Neurological impairment score and vibration perception also improved in the C-peptide treated group. Changes in glycaemic control could not account for the improved nerve function. 
There is also evidence suggesting that autonomic dysfunction in type 1 patients can be ameliorated by C-peptide administered at replacement doses. Short-term infusion of C-peptide is reported to significantly increase both heart rate variability during deep breathing and the heart rate brake index after tilting [11]. A similar but less marked improvement has been reported after 3 months of C-peptide administration [6].

Animal studies In BioBreeding/Worcester (BB/Wor) rats showing spontaneous development of type 1-like diabetes, administration of a replacement dose of C-peptide prevented diabetes-induced deterioration of NCV [12]. In addition, 3 months of C-peptide administration elicited a significant increase in NCV when treatment was commenced at 5 months after onset of diabetes, by which time nerve dysfunction had become established [12]. Similarly, in streptozotocin-induced diabetic rats receiving C-peptide from 6 to 8 weeks after induction of diabetes, a significant increase in both sensory (saphenous) and motor (sciatic) NCV was seen [13]; scrambled C-peptide had no effect. C-peptide replacement in diabetic rats reduced paranodal swelling by $60 \%$ at 2 months and resulted in near total prevention of axoglial dysjunction and paranodal demyelination at 8 months [12]. Marked improvements in structural abnormalities were also observed when C-peptide was given at 5-8 months after disease onset: axoglial dysjunction and paranodal demyelination improved significantly, axonal degeneration decreased and there was a fourfold increase in nerve fibre regeneration [12]. Replacement of C-peptide in $\mathrm{BB} /$ Wor rats is also reported to effectively prevent the development of thermal hyperalgesia and diminish the extent of unmyelinated fiber loss [14]. Furthermore, C-peptide administration in diabetic rats exposed to sciatic nerve crush injury has been found to improve axonal radial growth and elongation of regenerating fibres [15]. The combined evidence thus demonstrates beneficial effects of C-peptide on diabetes-induced functional and structural nerve abnormalities. A schematic representation of possible mechanisms of action is shown in Fig. 1.

C-peptide in replacement doses stimulates nerve $\mathrm{Na}^{+} / \mathrm{K}^{+}$ATPase activity, increases endoneurial blood flow and stimulates neurotrophic factors, resulting in improved $\mathrm{NCV}$ and prevention or reversal of nerve structural changes.

\section{Circulatory responses to C-peptide}

Administration of C-peptide in type 1 diabetes patients results in increased blood flow in several tissues. Skeletal

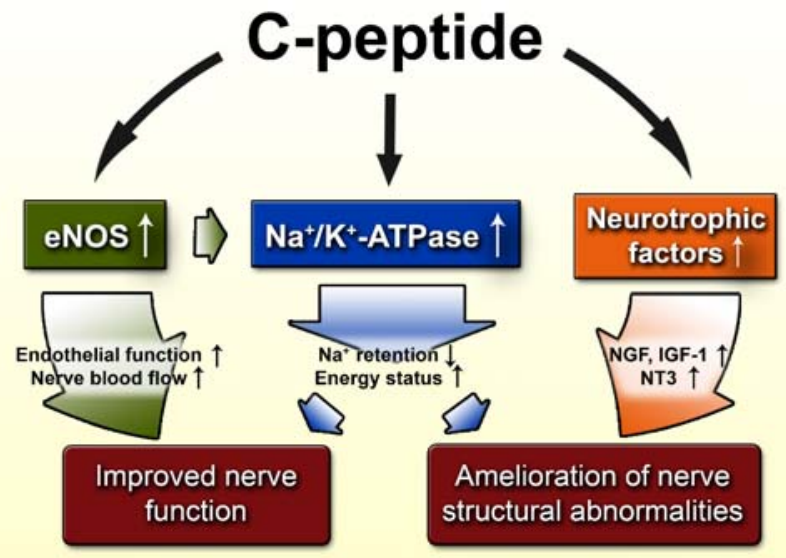

Fig. 1 Schematic representation of mechanisms whereby C-peptide may improve nerve function and ameliorate nerve structural abnormalities secondary to type 1 diabetes. For references, see Table 1 . $N G F$ nerve growth factor; NT3 neurotrophin 3

muscle perfusion (forearm) at rest and during exercise is increased in a concentration-dependent manner across the $0-1 \mathrm{nmol} / 1$ range, but higher concentrations of C-peptide elicit no further rise in blood flow [16]. In type 1 patients without signs of cardiac disease, C-peptide infusion results in augmented left ventricular blood flow. The patients also show improved rates of myocardial contraction, increased ejection fraction, plus a shortening of the QT interval [17, 18]. There is also augmented skin capillary blood cell velocity and redistribution of blood flow to nutritive capillaries following C-peptide administration [19]. Direct measurements of sciatic endoneurial blood flow in diabetic animals demonstrated augmented nerve perfusion in response to C-peptide administration [13, 20]. It is likely that the observed circulatory effects of C-peptide are mediated by stimulation and increased expression of endothelial nitric oxide synthase (eNOS) (see below), since the effect may be prevented by a NOS inhibitor [13]. An antithrombotic effect of C-peptide in diabetic mice has also been reported [21].

\section{Cell membrane interaction and intracellular signalling}

The nature of C-peptide cellular interactions has not been fully determined. Fluorescence correlation spectroscopy has shown the stereospecific binding of C-peptide to renal tubular cells, endothelial cells, skin fibroblasts, mesangial cells and neuroblastoma cells; the association constant was $3 \times 10^{9} \mathrm{l} / \mathrm{mol}$ and the binding curve indicated saturation at $0.9 \mathrm{nmol} / 1$ [22]. C-peptide binding did not show crossreactivity with insulin, IGF-1 or IGF-2. Binding of the peptide to detergent-solubilised cell fractions and cell lysates has also been demonstrated using fluorescence 
correlation spectroscopy and surface plasmon resonance [23], but there are no data based on conventional radioligand binding. It is unlikely that $\mathrm{C}$-peptide interacts directly with lipid cell membrane components [24]. The identity of the cellular binding structure has so far proven elusive and a specific receptor has not been identified.

Figure 2 provides an overview of intracellular responses to C-peptide. Most of the intracellular actions can be blocked by pre-incubation of cells with pertussis toxin, indicating the involvement of a $\mathrm{G}_{\mathrm{i}} / \mathrm{G}_{\mathrm{o}}$-linked protein in C-peptide signalling [25-28], as confirmed by direct studies assessing guanosine triphosphate $\gamma \mathrm{S}$ binding to a $\mathrm{G}_{\mathrm{i}}$ protein after C-peptide exposure [29]. Exposure of renal tubular and endothelial cells to C-peptide at physiological concentrations results in a prompt elevation of intracellular $\mathrm{Ca}^{2+}$ concentrations [27, 30]. C-peptide also elicits phosphorylation of several protein kinase $\mathrm{C}$ isoforms and phosphatidylinositol 3-kinase [26, 28, 31]. Activation of one or several components of the mitogen-activated protein (MAP) kinase cascade in a concentration-dependent manner is consistently observed in all examined cell types following exposure to C-peptide [26, 28, 32, 33]. C-peptide has also been found to mimic the effects of insulin in muscle cells [32].

\section{Cellular end effects}

eNOS C-peptide elicits release of NO in endothelial cells in a concentration- and time-dependent manner [30]. The effect, which occurs within a few minutes, is abolished in $\mathrm{Ca}^{2+}$-free medium and in the presence of pertussis toxin or a NOS inhibitor. In addition, increased expression of eNOS mRNA [34] and protein [33] has been demonstrated after exposure of endothelial cells to C-peptide; eNOS expression is enhanced via MAP kinase-dependent transcriptional activation [33]. The in vitro observations are consistent with the finding that C-peptide administration to type 1 patients and animal models of type 1 diabetes results in concentration-dependent increases in blood flow in several tissues, and suggest that C-peptide replacement in type 1 diabetes improves the diabetes-induced endothelial dysfunction [35]. Specifically, the C-peptide effect on nerve dysfunction may be mediated in part via a NO-sensitive vascular mechanism that elicits vasodilation of the vasa nervorum [13].

$\mathrm{Na}^{+} / \mathrm{K}^{+}$-ATPase C-peptide exerts a stimulatory effect on $\mathrm{Na}^{+} / \mathrm{K}^{+}$-ATPase activity and protein expression in renal tubular cells $[25,31,36]$. The effect is concentrationdependent, may be blocked by pertussis toxin, and is dependent on $\mathrm{Ca}^{2+}$ [25]. Decreased activity of this enzyme in peripheral nerve is a characteristic abnormality in type 1 diabetes. C-peptide at physiological concentrations prevents or partially corrects the diabetes-induced reduction in nerve $\mathrm{Na}^{+} / \mathrm{K}^{+}$-ATPase activity, both in streptozotocininduced diabetic animals [37] and in BB/Wor rats [12]. Moreover, the $\mathrm{Na}^{+} / \mathrm{K}^{+}$-ATPase activity of red blood cells is diminished in patients with type 1 diabetes; the
Fig. 2 Preliminary model of C-peptide signalling pathways. The influence of C-peptide on eNOS and $\mathrm{Na}^{+} / \mathrm{K}^{+}$-ATPase include both activation and induction. Dashed lines indicate insulinomimetic signalling demonstrated in muscle cells. $A T F 1$, activating transcription factor 1; CREB, cyclic AMP response element-binding protein; ERK1/2, extracellular signal-regulated kinase $1 / 2$; GTP $\gamma \mathrm{S}$, guanosine triphosphate $\gamma \mathrm{S}$; JNK, c-Jun N-terminal kinase; $P I 3-K$, phosphatidylinositol 3-kinase; $P K B$, protein kinase $\mathrm{B} ; P K C$, protein kinase C; $P L C$, phospholipase C; $P P A R \gamma$, peroxisome proliferatoractivated receptor $\gamma ; Z E B$, zinc finger homeodomain enhancerbinding protein

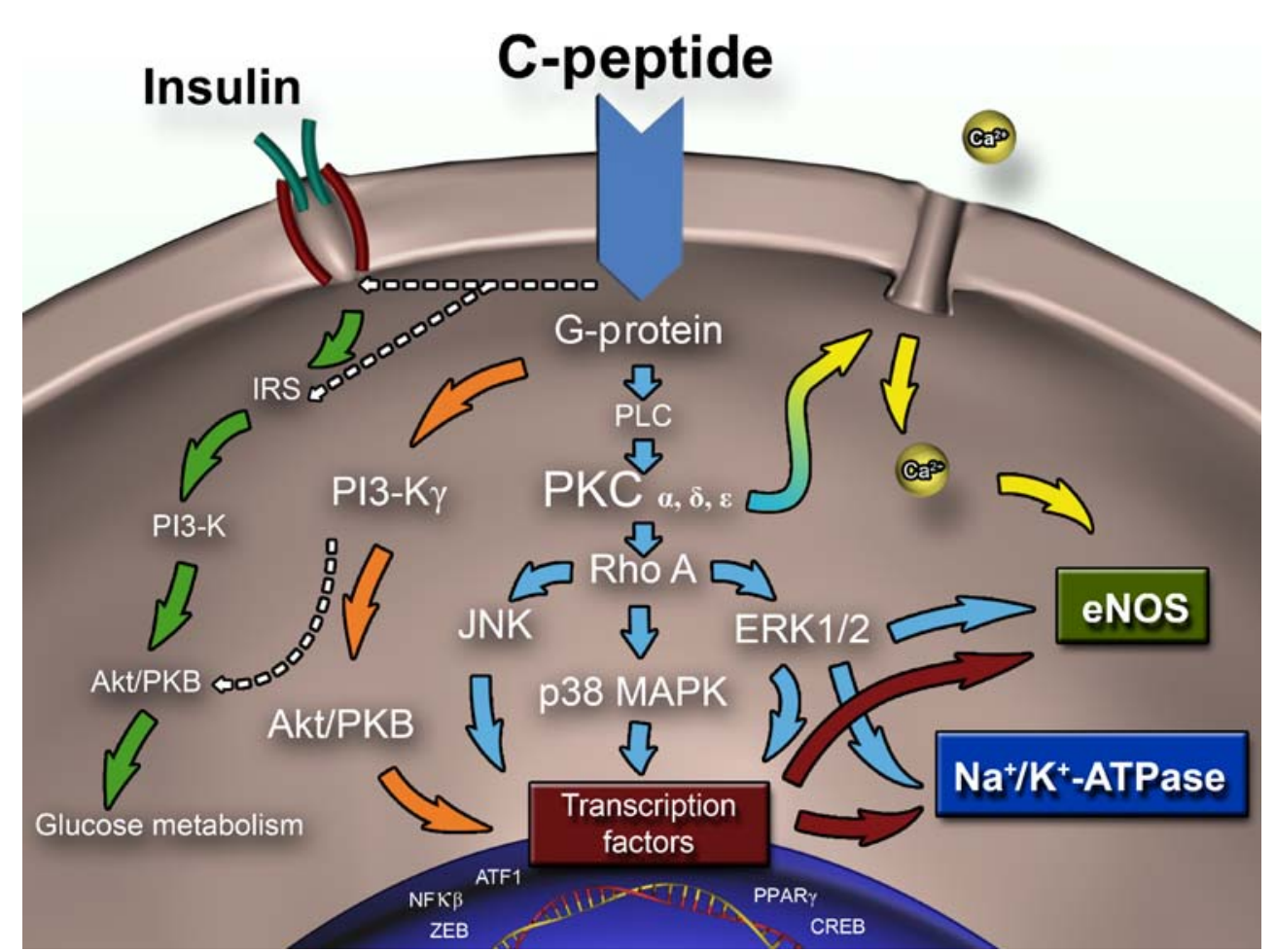


reduction is proportional to the decrease in C-peptide levels and can be corrected by C-peptide administration [38]. Secondary effects of the decreased red cell $\mathrm{Na}^{+} / \mathrm{K}^{+}$ATPase activity are impaired deformability of the cells and altered rheological properties; these are corrected after exposure to C-peptide [39]. Taken together, the evidence provides support for a direct relationship between C-peptide levels and $\mathrm{Na}^{+} / \mathrm{K}^{+}$-ATPase activity in renal and nerve tissue and red blood cells under both in vitro and in vivo conditions.

Transcriptional effects C-peptide causes activation and DNA binding of several transcription factors. Increased eNOS mRNA and protein levels [33] in endothelial cells have been discussed above. C-peptide is also reported to elicit decreased surface expression of the cell adhesion molecules P-selectin and intercellular adhesion molecule 1 on vascular endothelium, thereby inhibiting leucocyteendothelium interactions [34]. A stimulatory influence of C-peptide on cell proliferation has been reported for renal tubular [28] and neuroblastoma cells [40]. In the latter there was activation of phosphoinositol 3-kinase and p38 MAP kinase, resulting in enhanced expression and translocation of NFKB after C-peptide exposure. C-peptide has been found to protect against TNF $\alpha$-mediated apoptosis of renal tubular cells [29], and the anti-apoptotic effect of insulin on neuroblastoma cells grown at a high glucose concentration is significantly enhanced by C-peptide [40].

C-peptide binds specifically to cell membranes, resulting in G-protein-mediated intracellular signalling and activation of $\mathrm{Na}^{+} / \mathrm{K}^{+}$-ATPase, eNOS and several transcription factors.

\section{C-peptide-insulin interactions}

Interactions between C-peptide and insulin oligomers have been identified using surface plasmon resonance. Unexpectedly, it was discovered that C-peptide influences the disaggregation of insulin, probably by binding to insulin oligomers, with dissociation constants in the micromolar range [41]. Mass spectrometry revealed that insulin hexamers in solution became undetectable in the presence of $\mathrm{C}$-peptide, leading to the conclusion that $\mathrm{C}$-peptide binds to and causes disaggregation of hexameric insulin, increasing the availability of biologically active, monomeric insulin. Accordingly, subcutaneous injection of an insulin and C-peptide mixture in type 1 diabetes patients has been found to result in a more rapid appearance of insulin in plasma and more marked stimulation of glucose utilisation compared with injection of insulin alone [41].

\section{Not your regular peptide}

The physiological effects of C-peptide can be demonstrated only in patients or animals deficient in C-peptide and not in healthy individuals. The nature of the $\mathrm{C}$-peptide binding curve may help explain this unusual feature. The curve indicates saturation of cellular binding at approximately $0.9 \mathrm{nmol} / 1$ [22], which is within the physiological range. Thus, in healthy subjects and animals with normal beta cell function, receptor saturation is probably achieved at the ambient C-peptide concentration, so that no further effects can be expected in response to exogenous administration.

The structural variability of C-peptide in different species has been put forward as an argument that C-peptide is unlikely to possess biological activity. C-peptide is, however, not unique in this regard. Parathyroid hormone, gastrin-releasing peptide and relaxin all show similar interspecies variability. In addition, among mammalian species, nine residues (Glu1, Glu3, Gln6, Val7, Glu11, Leu12, Leu26, Glu27 and Gln31), localised primarily to the N- and C-terminal segments, show $\geq 90 \%$ conservation [42]. The exact functional correlates for these residues are not apparent, but Glu3, Glu11 and particularly Glu27 are all known to be important for the cellular effects of C-peptide [42].

\section{Are long-term complications different in type 1 and type 2 diabetes?}

The DCCT study demonstrated a decreased occurrence of complications in the group of type 1 diabetes patients that received intensive insulin therapy and achieved improved blood glucose control, in keeping with the view that hyperglycaemia is a major culprit in the pathogenesis of microvascular complications. Even though blood glucose levels were close to normal in the group that received intensive treatment, a large proportion of these patients still developed complications: $40 \%$ presented with clinical neuropathy or grossly abnormal nerve conduction after 5 years [43], and a similar fraction had developed signs of nephropathy or retinopathy. This suggests that factors in addition to hyperglycaemia may be involved in the development of microvascular complications in type 1 diabetes patients. In view of the data for C-peptide described above, we suggest that lack of C-peptide contributes to the pathogenesis of complications of type 1 diabetes. If this were the case, one would expect that the complications associated with type 1 diabetes would be different from those associated with type 2 . Direct comparisons have been made in patients and in animal models of diabetes, particularly with respect to neuropathy. Thus, neuropathy caused by type 1 diabetes occurs more 
predictably and progresses more rapidly than in type 2 diabetes. Both patients and experimental animals with type 1 diabetes neuropathy show characteristic structural abnormalities of the nodal and paranodal myelin sheath and ion channel barrier, which affect the large myelinated fibres in particular; these derangements are not seen in type 2 diabetes $[44,45]$. In addition, type 1 diabetic animals show progressive axonal degeneration coupled with impaired regenerative capacity, resulting in the gradual loss of nerve fibres, and this is either not present or significantly milder in animal models of type 2 diabetes [45]. Finally, in type 1 diabetes, but not in type 2, key nodal and paranodal molecules, e.g. contactin, caspr, and $\operatorname{ankyrin}_{\mathrm{G}}$ are downregulated [46]. In view of the above data, we propose that, besides hyperglycaemia, C-peptide deficiency is an important factor in the pathogenesis of neuropathy and possibly other microvascular complications of type 1 but not type 2 diabetes. Accordingly, type 1 diabetes should be considered a dual hormone deficiency disease and C-peptide replacement therapy may be beneficial in its treatment.

\section{Time for a new scientific perspective on C-peptide}

Why is it that despite the extensive documentation of multifaceted effects (Table 1), C-peptide is not yet generally recognised as a bioactive peptide? The fact that the peptide has no effects when administered to healthy animals or individuals may be partly responsible for this. An explanation for this unusual feature, based on the binding characteristics of the peptide, is presented above. Another complicating factor in this regard may be the lack of immediate or major effects of C-peptide withdrawal, as, for example, at the onset of type 1 diabetes. This may indicate that C-peptide is one of several players in the multifactorial system that regulates tissue microcirculation and endothelial function. The C-peptide contribution may be seen as redundant, at least in the short term. The presence of multiple regulatory mechanisms often signifies the vital importance of the specific physiological process being regulated, and the presence of compensatory regulation may help explain why a lack of C-peptide gives rise only to late manifestations that primarily occur in specific tissues. A third objection has been that the biological and clinical importance of C-peptide has not been established. This objection is refuted on the basis of the wealth of information now presented. Hence, we consider C-peptide to be bioactive.

Clearly, there is much more to learn about C-peptide. Identification of the mechanism whereby $\mathrm{C}$-peptide interacts with cell membranes and further delineation of its intracellular signalling pathways and transcriptional effects in different cell types would enhance our understanding of C-peptide bioactivity. On the clinical side, further studies of long duration will be required to document the robustness of its beneficial effects on the different types of long-term complications to define its possible therapeutic role in the therapy of type 1 diabetes, as also emphasised in the accompanying paper by Luzi et al. [47]. Nevertheless, despite the fact that our knowledge is still incomplete, there are several lines of evidence in support of the notion that C-peptide is a bioactive peptide and that its replacement in type 1 diabetes may be beneficial in the treatment of long-term complications. Specific cellular binding of the peptide, its intracellular signalling characteristics and end effects, including its action on eNOS, $\mathrm{Na}^{+} / \mathrm{K}^{+}$-ATPase and several transcription factors, are now established for many cell systems and by different investigators. Results from studies in type 1 diabetes patients and animal models demonstrate that, at replacement doses, C-peptide exerts beneficial effects on the early stage functional and structural abnormalities of both the kidneys and the peripheral nerves. Even a cautious evaluation of the available evidence thus presents the picture of a bioactive peptide with therapeutic potential.

Duality of interest The authors (J. Wahren, K. Ekberg, H. Jörnvall) hold shares in Creative Peptides (Stockholm, Sweden), and J. Wahren and K. Ekberg are employed by the company.

\section{References}

1. Sjöberg S, Gunnarsson R, Gjötterberg M, Lefvert A, Persson A, Östman J (1987) Residual insulin production, glycemic control and prevalence of microvascular lesions and polyneuropathy in longterm type 1 (insulin-dependent) diabetes mellitus. Diabetologia 30:208-213

2. Zerbini G, Mangili R, Luzi L (1999) Higher post-absorptive C-peptide levels in type 1 diabetic patients without renal complications. Diabet Med 16:1048-1049

3. Navarro X, Sutherland D, Kennedy W (1997) Long-term effects of pancreatic transplantation on diabetic neuropathy. Ann Neurol 42:727-736

4. Fiorina P, Folli F, Zerbini G et al (2003) Islet transplantation is associated with improvement of renal function among uremic patients with type I diabetes mellitus and kidney transplants. J Am Soc Nephrol 14:2150-2158

5. Johansson B-L, Sjöberg S, Wahren J (1992) The influence of human C-peptide on renal function and glucose utilization in Type I (insulin-dependent) diabetic patients. Diabetologia 35:121-128

6. Johansson B-L, Borg K, Fernqvist-Forbes E, Kernell A, Odergren T, Wahren J (2000) Beneficial effects of C-peptide on incipient nephropathy and neuropathy in patients with type I diabetes. Diabet Med 17:181-189

7. Sjöquist M, Huang W, Johansson B-L (1998) Effects of C-peptide on renal function at the early stage of experimental diabetes. Kidney Int 54:758-764 
8. Samnegård B, Jacobson S, Johansson B-L et al (2005) C-peptide prevents glomerular hypertrophy and mesangial matrix expansion in diabetic rats. Nephrol Dial Transplant 20:532-538

9. Ekberg K, Brismar T, Johansson B-L, Jonsson B, Lindström P, Wahren J (2003) Amelioration of sensory nerve dysfunction by C-peptide in patients with type 1 diabetes. Diabetes 52:536-541

10. Ekberg K, Brismar T, Johansson B-L et al (2007) C-peptide replacement therapy and sensory nerve function in type 1 diabetes neuropathy. Diabetes Care 30:71-76

11. Johansson B-L, Borg K, Fernqvist-Forbes E, Odergren $\mathrm{T}$, Remahl S, Wahren J (1996) C-peptide improves autonomic nerve function IDDM patients. Diabetologia 39:687-695

12. Sima AA, Zhang W, Sugimoto K et al (2001) C-peptide prevents and improves chronic type 1 diabetic polyneuropathy in the BB/ Wor rat. Diabetologia 44:889-897

13. Cotter M, Ekberg K, Wahren J, Cameron N (2003) Effects of proinsulin C-peptide in experimental diabetic neuropathy: vascular actions and modulation by nitric oxide synthase inhibition. Diabetes 52:1812-1817

14. Kamiya H, Zhang W, Sima AA (2004) C-peptide prevents nociceptive sensory neuropathy in type 1 diabetes. Ann Neurol $56: 827-835$

15. Pierson C, Zhang W, Sima A (2003) Proinsulin C-peptide replacement in type 1 diabetic $\mathrm{BB} /$ Wor-rats prevents deficits in nerve fiber regeneration. J Neuropathol Exp Neurol 62:765-779

16. Johansson B-L, Linde B, Wahren J (1992) Effects of C-peptide on blood flow, capillary diffusion capacity and glucose utilization in the exercising forearm of Type I (insulin-dependent) diabetic patients. Diabetologia 35:1151-1158

17. Johansson B-L, Sundell J, Ekberg K et al (2004) C-peptide improves adenosine-induced myocardial vasodilation in type 1 diabetes patients. Am J Physiol Endocrinol Metab 286:E14-E19

18. Hansen A, Johansson B-L, Wahren J, von Bibra H (2002) C-peptide exerts beneficial effects on myocardial blood flow and function in patients with type 1 diabetes. Diabetes 51:3077-3082

19. Forst T, Kunt T, Pohlmann T et al (1998) Biological activity of C-peptide on the skin microcirculation in patients with insulin dependent diabetes mellitus. J Clin Invest 101:2036-2041

20. Stevens M, Zhang W, Li F, Sima A (2004) C-peptide corrects endoneurial blood flow but not oxidative stress in type $1 \mathrm{BB} /$ Wor rats. Am J Physiol Endocrinol Metab 287:E497-E505

21. Lindenblatt N, Braun B, Menger M, Klar E, Vollmar B (2006) C-peptide exerts antithrombotic effects that are repressed by insulin in normal and diabetic mice. Diabetologia 49:792-800

22. Rigler R, Pramanik A, Jonasson P et al (1999) Specific binding of proinsulin C-peptide to human cell membranes. Proc Natl Acad Sci USA 96:13318-13323

23. Henriksson M, Pramanik A, Shafqat J et al (2001) Specific binding of proinsulin C-peptide to detergent-solubilised human skin fibroblasts. Biochem Biophys Res Commun 280:423-427

24. Henriksson M, Shafqat J, Liepinsh E et al (2000) Unordered structure of proinsulin C-peptide in aqueous solution and in the presence of lipid vesicles. Cell Mol Life Sci 57:337-342

25. Zhong Z, Kotova O, Davidescu A et al (2004) C-peptide stimulates $\mathrm{Na}^{+}, \mathrm{K}^{+}$-ATPase via activation of ERK1/2 MAP kinases in human renal tubular cells. Cell Mol Life Sci 61:2782-2790

26. Zhong Z, Davidescu A, Ehrén I et al (2005) C-peptide stimulates ERK1/2 and JNK MAP-kinases via activation of PKC in human renal tubular cells. Diabetologia 48:187-197

27. Shafqat J, Juntti-Berggren L, Zhong $Z$ et al (2002) Proinsulin $\mathrm{C}$-peptide and its analogues induce intracellular $\mathrm{Ca}^{2+}$ increases in human renal tubular cells. Cell Mol Life Sci 59:1185-1189

28. Al-Rasheed N, Meakin F, Royal E et al (2004) Potent activation of multiple signalling pathways by C-peptide in oppossum kidney proximal tubular cells. Diabetologia 47:987-997
29. Al-Rasheed N, Willars G, Brunskill N (2006) C-peptide signals via $\mathrm{G}_{\alpha \mathrm{i}}$ to protect against TNF- $\alpha$-mediated apoptosis of opossum kidney proximal tubular cells. J Am Soc Nephrol 17:986-995

30. Wallerath T, Kunt T, Forst $T$ et al (2003) Stimulation of endothelial nitric oxide synthase by proinsulin C-peptide. Nitric Oxide 9:95-102

31. Tsimaratos M, Roger F, Chabardès D et al (2003) C-peptide stimulates $\mathrm{Na}, \mathrm{K}$-ATPase activity via PKC alpha in rat medullary thick ascending limb. Diabetologia 46:124-131

32. Grunberger G, Qiang X, Li Z et al (2001) Molecular basis for the insulinomimetic effects of C-peptide. Diabetologia 44: $1247-1257$

33. Kitamura T, Kimura K, Makondo K et al (2003) Proinsulin C-peptide increases nitric oxide production by enhancing mitogen-activated protein-kinase-dependent transcription of endothelial nitric oxide synthase in aortic endothelial cells of Wistar rats. Diabetologia 46:1698-1705

34. Scalia R, Coyle K, Levine B, Booth G, Lefer A (2000) C-peptide inhibits leukocyte-endothelium interaction in the microcirculation during endothelial dysfunction. FASEB J 14:2357-2364

35. Joshua I, Zhang Q, Falcone J, Bratcher A, Rodriguez W, Tyagi S (2005) Mechanisms of endothelial dysfunction with development of type 1 diabetes mellitus: role of insulin and C-peptide. J Cell Biochem 96:1149-1156

36. Chibalin A, Zhong Z, Kotova O, Ehrén I, Ekberg K, Wahren J (2006) Physiological concentrations of C-peptide increase Na,KATPase expression via PKC- and MAP kinase dependent activation of transcription factor ZEB in human renal tubular cells. Diabetologia 49(Suppl 1):A348

37. Ido Y, Vindigni A, Chang K et al (1997) Prevention of vascular and neural dysfunction in diabetic rats by $\mathrm{C}$-peptide. Science 277:563-566

38. Forst T, Dufayet De La Tour D, Kunt T et al (2000) Effects of proinsulin C-peptide on nitric oxide, microvascular blood flow and erythrocyte $\mathrm{Na}^{+}, \mathrm{K}^{+}$ATPase activity in diabetes mellitus type 1. Clin Sci (Lond) 98:283-290

39. Kunt T, Schneider S, Pfützner A et al (1999) The effect of human proinsulin C-peptide on erythrocyte deformability in patients with type 1 diabetes mellitus. Diabetologia 42:465-471

40. Li Z, Zhang W, Sima A (2003) C-peptide enhances insulinmediated cell growth and protection against high glucoseinduced apoptosis in SH-SY5Y cells. Diabetes/Metab Res Rev 19:375-385

41. Shafqat J, Melles E, Sigmundson K et al (2006) Proinsulin $\mathrm{C}$-peptide elicits disaggregation of insulin resulting in enhanced physiological insulin effects. Cell Mol Life Sci 63:1805-1811

42. Henriksson M, Nordling E, Melles E et al (2005) Separate functional features of proinsulin C-peptide. Cell Mol Life Sci 62:1772-1778

43. DCCT Group (1995) Effect of intensive diabetes treatment on nerve conduction in the diabetes control and complications trial. Ann Neurol 38:869-880

44. Sima AA, Nathaniel V, Bril V, McEwen T, Green D (1988) Histopathological heterogeneity of neuropathy in insulin-dependent and non-insulin-dependent diabetes, and demonstration of axo-glial dysjunction in human diabetic neuropathy. J Clin Invest 81:349-364

45. Sima AA (2004) Diabetic neuropathy in type 1 and 2 diabetes and the effect of C-peptide. J Neurol Sci 220:133-136

46. Sima A, Zhang W, Li Z, Murakawa Y, Pierson C (2004) Molecular alterations underlie nodal and paranodal degeneration in type 1 diabetic neuropathy and are prevented by C-peptide. Diabetes 53:1556-1563

47. Luzi L, Zerbini G, Caumo A (2007) C-peptide: a redundant relative of insulin? Diabetologia. doi: 10.1007/s00125-0060576-x 